\title{
Ovarian Choriocarcinoma
}

National Cancer Institute

\section{Source}

National Cancer Institute. Ovarian Choriocarcinoma. NCI Thesaurus. Code C4515.

A choriocarcinoma arising from the ovary. When it appears before puberty is of germ cell origin. In children and young adults signs and symptoms include precocious pseudopuberty and vaginal bleeding. Serum human chorionic gonadotropin is elevated. Germ cell derived ovarian choriocarcinoma should be differentiated from primary or metastatic gestational choriocarcinoma affecting the ovary. The prognosis of germ cell derived choriocarcinoma is less favorable and requires more aggressive chemotherapy treatment regimens compared to gestational choriocarcinoma. 